\title{
The relationship between polymyalgia rheumatica, giant cell artritis and varicella zoster leading to a treament for GCA
}

\author{
Taylor $\mathrm{A}^{1 *}$ and Brooksbank $\mathrm{KL}^{2}$ \\ ${ }^{1}$ St. Cross College, St Giles, Oxford OX1 3LZ, UK \\ ${ }^{2}$ Girvan Community Hospital, Girvan, Ayrshire KA26 9HQ, UK
}

\section{Introduction}

Giant Cell Artritis (GCA) is an unpleasant condition that can cause serious complications. The standard treatment involves the prolonged use of steroids which in itself causes problems. Because of the published evidence of the involvement of the Herpes zoster virus with GCA, treatment with a large dose of acyclovir was tried. The treatment was successful and after a few days all symptoms of GCA had disappeared.

Polymyalgia rheumatic was first identified as a distinct disease some 130 years ago; however, the aetiology is still uncertain. It has been observed that the incidence of PMR appears to follow a cyclical pattern and that there is seasonal variation Smeeth [1]. These observations, together with the fact that there is recovery from a general inflammation response, was thought to be indicative of an infectious aetiology. Many authors have suggested the possibility of a viral cause [2]. However there have been a number of studies looking for a viral involvement without success [3-7].

It has been observed that PMR and Giant cell artritis are often co-incidental [8-9]. Cantini suggested that the epidemiology of PMR and GCA is such that they are linked, but a cause has not been found. Smeeth found a remarkable correlation between the incidence of PMR and GCA. A statistical analysis by Salvarani showed that the frequency of the association was way above what would be expected by chance [10]. Rooney quoted figures showing that $15 \%$ of PMR sufferers also have Giant cell artritis while 55\% of GCA sufferers also have PMR [11]. In 2015 Gilden determined the prevalence and distribution of Varicella zoster virus in biopsies taken from temporal arteries of patients with GCA. This was confirmed by Gilden who did a blinded search for VZV in GCA positive patients, it was found that $78 \%$ of the temporal artery biopsies from patients with GCA had Varicella zoster virus in the cells [12-13]. Gilden also confirmed presence of VZV in muscle cells attached to the temporal artery and proposed that VZV is the cause of GCA [14]. In cases of GCA where biopsies were negative for VZV, Nagel identified the presence of VZV antigens [15].

\section{Case notes}

The patient, a retired virologist, reported with the classical symptoms of PMR, shoulder stiffness and weakness of both anterior and posterior thigh muscles. The erythrocyte sedimentation rate was $70 \mathrm{~mm} / \mathrm{hr}$ and the C-reactive protein $12 \mathrm{mg} / \mathrm{l}$. A dose of $15 \mathrm{mg} /$ day of prednisolone was prescribed. The day after the first dose, all symptoms had disappeared. The patient continued on $15 \mathrm{mg}$ /day for 3 weeks then reduced dose of prednisolone to $12.5 \mathrm{mg}$ /day for 3 weeks then reduced

to $10 \mathrm{mg} /$ day. The patient then developed classical symptoms of Giant Cell Artritis; swollen and painful temporal arteries and painful jaw claudication with swollen and very painful sub mandibular and parotid lymph glands. The ESR was $73 \mathrm{~mm} / \mathrm{hr}$. and the CRP $29 \mathrm{mg} / \mathrm{l}$. The dose of prednisolone was immediately restored to $15 \mathrm{mg}$ /day. It was decided to treat the presumed viral cause with a large dose of aciclovir. ${ }^{15}$ The dose prescribed was $5 \times 0.8 \mathrm{~g}$ aciclovir/day for five days. After four days all the above symptoms had disappeared. After five days the dose was reduced to $1 \times 0.8 \mathrm{~g} /$ day. However four days later all symptoms had reappeared. The aciclovir dose was changed to $4 \mathrm{x} 0.8 \mathrm{~g} / \mathrm{day}$ for seven days and then continued at $2 \times 0.8 \mathrm{~g} /$ day for 8 weeks. Again, after four days all the painful symptoms of GCA had disappeared, the swollen and hard temporal arteries returned to normal over the course of four to six weeks and the ESR dropped to $17 \mathrm{~mm} / \mathrm{hr}$. The symptoms of GCA have not reappeared 9 months after stopping the antiviral. In this time the steroid dose has been gradually reduced to $5 \mathrm{mg}$ /day of prednisolone.

The male patient was age 79 , weighed $88 \mathrm{~kg}$ and had no condition that would predicate against a high dose of acyclovir.

\section{Discussion}

Because of the suspicion that Varicella zoster is linked to the cause of GCA and that because of the proven association of GCA and Polymyalgia rheumatica, it seems that there is an unexplained link between GCA and PMR and by implication between VZV and PMR. Because of this, a number of the above authors have recommended the addition of an antiviral drug to the standard steroid treatment of GCA and PMR. Aciclovir has also been used on patients who had relapsed after six months of steroids. Another antiviral, famcyclovir has also been used at the same time as the steroid treatment [11].

The antiviral activity of acyclovir is limited to members of the Herpes virus family. It shows potent antiviral activity against Herpes simplex types 1 and 2 and the Varicella Zoster virus. The rapid improvement in the GCA symptoms in the patient concerned, would also point to the involvement of VZV in GCA. However in order to prove causality, it would be necessary to run a trial using steroids plus acyclovir versus steroids alone, in biopsy proven presence of VZV in

Correspondence to: Taylor A, St. Cross College, St Giles, Oxford OX1 3LZ, UK, E-mail: alan.taylor@stx.oxon.org

Received: February 19, 2018; Accepted: March 23, 2018; Published: March 29, 2018 
cases of GCA. The problem with this is, that a temporal artery biopsy is of no direct benefit to the patient and therefore difficult to justify. In the case reported, the patient refused permission and as the symptoms were classical for GCA a biopsy was not thought to be necessary.

Because acyclovir is well tolerated and does not have the problems that occur when reducing the level of prednisolone, it would be of great benefit, if it were to become the treatment of first resort for Giant Cell Artritis.

\section{Acknowledgment}

The authors wish to acknowledge and thank Professor Peter Kennedy of the College of Medical Sciences, University of Glasgow, for his most helpful advice.

\section{References}

1. Smeeth L, Cook C, Hall AJ (2006) Incidence of diagnosed polymyalgia rheumatica and temporal arteritis in the UK 1990-2001. Ann Rheum Dis 65: 1093-1098. [Crossref]

2. Turnbull J (1996) Temporal arteritis and polymyalgia rheumatica: nosographic and nosologic considerations. Neurology 46: 901-906. [Corssref]

3. Duhaut P, Pinede L, Bornet H, DuMontet C, Ninet J, et al. (1999) Giant Cell arteritis and Polymyalgia rheumatica a viral hypothesis: A multicenter prospective case study. $J$ Rheumatol 2: 361-369. [Crossref]

4. Duhaut P, Bossard S, Ducroix JP (2004) Is GCA an infectious disease? Biological and Epidemiological evidence. Presse Med 33: 1403-1408. [Crossref]
5. Soriano A (2012) Giant cell arteritis and polymyalgia rheumatica after influenza vaccination: report of 10 cases and review of the literature. Lupus 25: 153-157. [Crossref]

6. Gabriel SE, Espy M, Erdman DD, Bjornson J, Smith TF (1999) The role of parvovirus $\mathrm{B} 19$ in the pathogenesis of giant cell arteritis: a preliminary evaluation. Arthritis Rheum 42: 1255-1258. [Crossref]

7. Kennedy PG, Grinfield E, Esini MM (2003) Absence of detection of varicella-zoster virus DNA in temporal artery biopsies obtained from patients with giant cell arteritis. $J$ Neurol Sci 215: 27-29. [Crossref]

8. Elling P, Ollson AT, Elling H (1996) Synchronous variations of the incidence of temporal arteritis and polymyalgia rheumatica in different regions of Denmark; association with epidemics of Mycoplasma pneumoniae infection. J Rheumatol 1: 112-119. [Crossref]

9. Cantini F, Nicoli L, Storm L, Nannini C, Oliviera I (2004) Are polymyalgia rheumatica and giant cell arteritis the same disease? Sem Arthritis Rheum 33: 294-301. [Crossref]

10. Salvarani C, Pipitone C, Versani A, Hunde G (2012) Clinical features of polymyalgia rheumatica and giant cell arteritis. Nat Rev Rheumatol 9: 509-521. [Crossref]

11. Rooney PJ, Rooney J, Balint G (2015) Polymyalgia rheumatica 125 years of epidemiological progress. Scot Med J 60: 50-57. [Crossref]

12. Gilden D (2015) Prevalence and distribution of VZV in temporal arteries of patients with Giant Cell Arteritis. Neurology 84: 1918-1919. [Crossref]

13. Gilden D, White T, Khmelova N, Katz BJ, Nagel M (2016) Blinded search for varicella zoster virus in giant cell arteritis (GCA)-positive and GCA-negative temporal arteries. J Neurol Sci 364:141-143. [Crossref]

14. Gilden D, Nagel M (2015) Varicella Zoster virus in Temporal arteries of patients with Giant Cell Arteritis. J Infectious Dis 212: S37-39. [Crossref]

15. Kennedy PG (2016) Issues in the treatment of Neurological conditions caused by the reactivation of Varicella Zoster virus (VZV). Neurotherapeutics 3: 509-513. [Crossref]

Copyright: (C2018 Taylor A. This is an open-access article distributed under the terms of the Creative Commons Attribution License, which permits unrestricted use, distribution, and reproduction in any medium, provided the original author and source are credited. 